\title{
Syria-Israel Relations in Al-Assad's Speeches and Interviews: A Corpus-Assisted Critical Discourse Study
}

\author{
Linda S. Al-Abbas \\ Department of English Language and Literature, Middle East University, Amman, Jordan
}

\begin{abstract}
This paper uses a 1,445,000-word corpus to examine Syria-Israel relations in the speeches and interviews of Syrian President Basher Al-Assad from 2000 to 2016. Van Dijk's (2009) notions of manipulation and polarization are employed to highlight the discursive strategies that Al-Assad uses to legitimize his points of view regarding a range of regional issues. Examining how Al-Assad constructed Israel* in his speeches revealed recurrent thematic categories, such as conflict, occupation, negotiation, and criminality/violence. The analysis suggests that Al-Assad used Israel to build solidarity with his people portraying himself as a man of values who does his best to resist the occupier and liberate the occupied Arab lands.
\end{abstract}

Index Terms-Bashar Al-Assad, corpus linguistics, critical discourse analysis, presidential speeches

\section{INTRODUCTION}

Syria is an Arab country located in Western Asia on the eastern coast of the Mediterranean Sea. The Syrian regime is a Republican presidential system, and the Syrian President is Bashar al-Assad at the time of writing (Haider, 2019a). Syria is a founding member of the Arab League from which it is currently suspended as a consequence of the era of Arab spring (Syrian Uprisings) (Küçükkeleş, 2012).

There are different means through which people can make sense of the world around them, and no one can ignore the fact that language is considered one of the best tools to do that. However, whether language is a neutral tool that reflects social activities with no manipulation is critical. Language is not a simple means of communication and does not act passively in the world. It may function as an ideological tool that constructs and represents meaning in a planned way to affect and influence people's opinions about this world (see Al-Abbas \& Haider, 2020; Haider, 2019c; Haider \& Olimy, 2019). For example, referring to the Arab countries that reject signing peace treaties with Israel in different ways, including "anti-occupation" countries, may indicate that their opponents are "pro-occupation" countries, although this idea is not mentioned or stated.

To emphasize the idea that language is not used randomly and the text producers may have a variety of choices but still tend to prefer using particular structures or lexical items rather than others, Schegloff (1997) states that any person can be characterized using different sets of category terms such as gender, age, ethnicity, nationality, occupation, and many other features. For example, it is not sufficient to call the president of Syria between 1971 and 2000 "Bashar's father" and then justify it by saying that it is true since he is in the same token. The same issue applies to other contexts. For example, we may refer to the same place using different descriptions. Syria can be referred to as the Levant (AlSham), a country in the Middle East, a country that borders Jordan to the south, a country that has occupied territories called the Golan Heights, etc. The speaker's choices to describe a situation are usually based on their political stance, attitude, and ideology.

A powerful and influential discourse is achieved by a powerful speaker or writer (e.g., presidents), someone being accessed by many people (is received by a lot of people), and having the same patterns repeated over and over in everyday language. These criteria apply to Bashar Al-Assad's speeches and interviews. They are produced by the most powerful authority in the country, which motivates people to listen to his speeches bearing in mind that most of his linguistic patterns appear repetitively in the local, national, and international media during and immediately after the speech or interview. Hence, this study investigates Bashar Al-Assad's speeches and interviews between 2000 and 2016 by combining Critical Discourse Analysis (CDA) and Corpus Linguistics (CL) to examine how Israel is discursively represented. It mainly addresses the following questions:

(1) How is Israel constructed in the speeches and interviews of Al-Assad?

(2) Are there any differences in the ways Al-Assad refers to Israel before and during the Syrian uprisings?

\section{CONTEXTUAL BACKGROUND}

A. Bashar Al-Assad 
Bashar al-Assad, born on September 11, 1965, is the president of the Syrian Arab Republic and the son of former Syrian President Hafez al-Assad. Al-Assad took over the presidency after a public referendum in 2000 following his father's death, who ruled Syria from 1971 to 2000 . He is the commander of the Syrian Army and armed forces and the Regional Secretary of the Baath Arab Socialist Party, the ruling party in the country since 1963. Before joining politics, Al-Assad was a doctor specializing in ophthalmology in London. In 1994, he returned to Damascus after the death of his brother, Basil al-Assad, in a car accident. The anti-American and Israeli hegemony characterized his foreign policy. Despite the relative openness in his era compared to his father's, his domestic policies were marred by administrative and political corruption and the emergence of businesspeople who controlled the country's economy and policies.

\section{B. The Arab Spring \& Syrian Uprisings}

The term 'Arab Spring refers to related events, namely the massive protest movements that began in some Arab countries, mainly Tunisia, Egypt, Libya, Yemen, Syria, in late 2010 and are ongoing (Haider, 2016). Influenced by the Tunisian uprisings on December 18, 2010, the Syrian protests began in 2011 against the Syrian ruling regime's repression and suppression of freedoms.

\section{Syria-Israel Relations}

There has been no diplomatic relation between Syria and Israel since their establishment. However, the two countries were involved in some major wars in the modern history of the Middle East, among which are the 1948, 1967, and 1973 wars, in addition to their attempts to interact in the Lebanese Civil War (1975- 1990). During the Six-Day War (1967 War), the Golan Heights (Syrian territory) was occupied by Israel. Syria has tried hard to recover its occupied lands several times but was unsuccessful. In 1982, during the Lebanese Civil War, Israel invaded southern Lebanon to dislodge the Palestine Liberation Organization. As a response, Syria sent both ground and air forces to the Lebanese territories but was massively defeated by Israel. During Madrid Conference in 1991, some negotiations were held with the late Syrian President, Hafez Al-Assad, to resolve the conflict with Israel, but were unsuccessful despite the severe attempts to find a permanent resolution. In 2003, the Israeli Air Forces attacked a camp near Damascus, claiming that it is used to train Palestinian militants. In 2007, Israel held another attack, but this time against alleged Syria's nuclear program. In 2006 and during the Israel-Hezbollah War (a 34-day military conflict in Lebanon and northern Israel), Syria was accused of supporting the Lebanese resistance, represented by Hezbollah, by allowing Iran to ship supplies to Lebanon through its territory. Turkey made peace talks between Syria and Israel, but the Syrian side withdrew after the Israeli's massacres in Gaza in 2008/2009. During the Syrian uprising (2011-ongoing), there have been several crossborder shooting incidents in the demilitarized area of Golan Heights, but with no response from the Syrian side.

\section{THEORETICAL BACKGROUND}

\section{A. Corpus Linguistics and Critical Discourse Analysis}

Corpus Linguistics is a methodology (McEnery \& Wilson, 2001) used to tackle some aspects across the disciplines and theories of linguistics such as lexicography, pedagogy, sociolinguistics, discourse analysis, and others based on real-life examples. Baker (2010, p. 1) defines a corpus as "a large collection of computerized texts, usually carefully sampled to be representative of a particular language variety." Critical Discourse Analysis is a relatively new and developed area of language study in which discourse is treated according to Fairclough and Wodak (1997, p. 258) as "a form of social practice." It investigates the relationship between language and power, considering the crucial role that the context plays in discourse (Wodak, 2009). CDA is critical because it is discourse analysis with an attitude (Haider, Al-Salman, \& Al-Abbas, 2021) and due to its commitment to the analysis of social wrongs such as prejudice or unequal access to power, privileges, and material and symbolic resources (Fairclough, 2009), and because of its explicit and unapologetic attitude as far as values and criteria are concerned (Van Leeuwen, 2006). CDA has been a target for many criticisms; such as eclecticism of theories, the ideological bias of the analysts choosing the texts that suit their preconceived theories and confirm their beliefs "looking in the wrong place for something, then complain that they can't find it, and suggest that it is being concealed from them" (Sharrock \& Anderson, 1981, p. 291), and fragmentation of data (Stubbs, 1997). As a result, many changes have happened to CDA since its establishment, utilizing large corpora rather than sticking to short excerpts.

Hardt-Mautner (1995) mentioned some advantages of using CL techniques in discourse analysis studies stating that such combination enables researchers, with the help of computers, to describe some textual properties in an exhaustive rather than selective way in addition to drawing the researchers' attention to some research questions that they were not aware of. Baker et al. (2008) suggested that the methodological synergy between CL and CL demonstrates the fuzzy boundaries between 'quantitative' and 'qualitative' approaches showing that 'qualitative' findings can be quantified and that 'quantitative' findings can be explained based on the existing theories and hypotheses and may result in their adaptation, or the formulation of new ones. The number of discourse analysis studies with the aid of corpus linguistics is still limited for some reasons. One of them is related to the fact that the notion of combination is relatively new. Another reason is its cross-disciplinary nature which appears to be subject to some resistance. Baker (2006) interpreted such a limited number as a kind of misconception of corpus linguistics, unfamiliarity with computers, and the ability to find valid and suitable topics to investigate using both methods. 


\section{B. Corpus Linguistic Techniques Used in This Study}

Although the methodologies and analytical techniques of corpus linguistics are wide-ranging, certain practices are common across many different studies, for example, examining word frequencies, examining concordance lines, and carrying out collocation analysis (Haider, 2019b). Word frequency is a cornerstone of corpus linguistics. It is important for corpus-assisted discourse studies as $\mathrm{CDA}$ has been criticized for focusing on unusual language rather than usual or highly frequent occurrences (O'Halloran, 2000). In CL, a very common way to analyze context or co-text is to use a concordance, which presents given words along with their immediate surrounding words (Haider \& Hussein, 2019). It is rare, if not impossible, to find a corpus-based/driven discourse analysis without using this tool. Baker (2010) mentions two reasons why concordance is fundamental for discourse analysis: it allows analysts to uncover evidence for various prosodies or preferences. Without it, analysts are liable to make incorrect assumptions about the content of their corpora.

Another CL technique is collocation which refers to the words usually observed together or in close proximity in naturally occurring language. Bartsch (2004, p. 76) defines collocations as "lexically and/or pragmatically constrained recurrent co-occurrences of at least two lexical items which are in direct syntactic relation with each other." A statistical definition of collocation which is adopted by corpus linguists is introduced by Stubbs (2001, p. 29), who stated, "my definition is [...] a statistical one: "collocation" is frequent co-occurrence." A collocation analysis is important for CDA analysts since it helps researchers to have an initial focus (saliency) of the investigated item in addition to suggesting unconscious associations in a short period when compared with concordance, which needs to be sorted in different ways before identifying the relationship between patterns in the text. Gabrielatos and Baker (2008) point out that collocation analysis can provide evidence that supports, refutes, or modifies conclusions based on small-scale qualitative studies.

\section{Van Dijk's Triangular Approach and Syrian-Israeli Relations}

The socio-cognitive model (Van Dijk, 2004) combines both cognitive psychology and CDA to show how certain ideologies are hidden in people's minds. Van Dijk (2004) incorporates three constituents to analyze discourse, namely, social analysis (investigating the context/ overall societal structures), cognitive analysis (social cognition and personal cognition), and discourse analysis (examining and analyzing the text syntax, semantics...). What distinguishes this approach from others is inserting the cognitive model to mediate between society (context) and discourse (text). For Van Dijk (1995), memory is broken down into short-term memory and long-term memory. The actual processing of information (discourse) occurs in short-term memory against information stored in long-term memory (discourses). Long-term memory is broken down into episodic memory and semantic memory; episodic memory refers to information stored through personal experiences, while semantics memory refers to more general abstract and socially shared information. For language users, experiencing and participating in many thousands of communicative situations such as reading hundreds of newspapers' articles or listening to speeches and interviews in which $\mathrm{X}$ is described as a terrorist, for example, they might generalize and normalize this, and this will be part of their episodic memory. As a result, this will determine how they act in society and deal with X. The cognitive analysis, according to Van Dijk (1995), combines both personal cognition and social cognition as the process discussed in the previous couple of lines does not only happen in the mind of an individual but in the minds of the majority of people experiencing the same events and exposing the same discourse bearing in mind that individuals live in a community, read similar newspapers, and interact with each other.

\section{Methodology}

\section{A. Corpus Compilation and Data Source}

This study uses a comparable corpus that consists of 1,445,117 words. The data were collected from http://www.presidentassad.net, a website with considerable information about Al-Assad family, including the current President Bashar Al-Assad, late President Hafez Al-Assad, and Asma' Al-Akhras (Bashar Al-Assad's wife). The website is maintained by a Syrian journalist and is based in Syria. Table (1) shows the number of Al-Assad's speeches and interviews delivered in or translated into English/Arabic from 2000 to 2016. As explained above, the data is divided into two main sub-corpora based on its occurrence before or during the uprisings. The word count for each sub-corpus is provided with the number of speeches and interviews each year. In this study, the researcher investigated the English part of the corpus. 
TABLE 1

ASSAD's SPEECHES AND INTERVIEWS (2000-2016)

\begin{tabular}{|c|c|c|c|c|c|}
\hline \multicolumn{6}{|c|}{ Comparable Corpus of the Speeches and Interviews of Al-Assad } \\
\hline \multicolumn{6}{|c|}{ Before the Uprisings } \\
\hline \multirow{14}{*}{ Period 1} & Language & \multicolumn{2}{|c|}{ English } & \multicolumn{2}{|c|}{ Arabic } \\
\hline & Year & $\begin{array}{c}\text { No. of speeches/ } \\
\text { Interviews }\end{array}$ & Word count & $\begin{array}{c}\text { No. of speeches/ } \\
\text { Interviews }\end{array}$ & Word count \\
\hline & 2000 & 7 & 12201 & 5 & 10,900 \\
\hline & 2001 & 7 & 12479 & 13 & 25,164 \\
\hline & 2002 & 6 & 15862 & 7 & 13,599 \\
\hline & 2003 & 11 & 33310 & 6 & 18,516 \\
\hline & 2004 & 5 & 11256 & 5 & 17,389 \\
\hline & 2005 & 7 & 35488 & 9 & 30,700 \\
\hline & 2006 & 9 & 38890 & 10 & 48,298 \\
\hline & 2007 & 10 & 16351 & 10 & 22,984 \\
\hline & 2008 & 24 & 42202 & 17 & 31,212 \\
\hline & 2009 & 33 & 46704 & 24 & 60,336 \\
\hline & 2010 & 27 & 66897 & 33 & 72,285 \\
\hline & Total & 146 & 331640 & 139 & 351,383 \\
\hline \multirow{8}{*}{ Period 2} & \multicolumn{5}{|c|}{ During the Uprisings } \\
\hline & 2011 & 9 & 58428 & 6 & 25,673 \\
\hline & 2012 & 10 & 54150 & 9 & 38,395 \\
\hline & 2013 & 21 & 96609 & 21 & 96,649 \\
\hline & 2014 & 5 & 16874 & 3 & 12,125 \\
\hline & 2015 & 19 & 104165 & 19 & 87,282 \\
\hline & 2016 & 19 & 85677 & 19 & 86,067 \\
\hline & Total & 83 & 415903 & 77 & 346,191 \\
\hline \multicolumn{2}{|c|}{ Arabic and English } & 229 & 747,543 & 219 & 697,574 \\
\hline
\end{tabular}

\section{B. Data Analysis}

Wordsmith 7 (WS7) (Scott, 2016) was used to create a word list, i.e. a list of all the words in the corpus and their frequencies. Israel and its derivatives are among the most frequent words in the corpus, being mentioned 1634 times. Figure 1 shows the mentions of Israel* before and after the Arab uprisings.

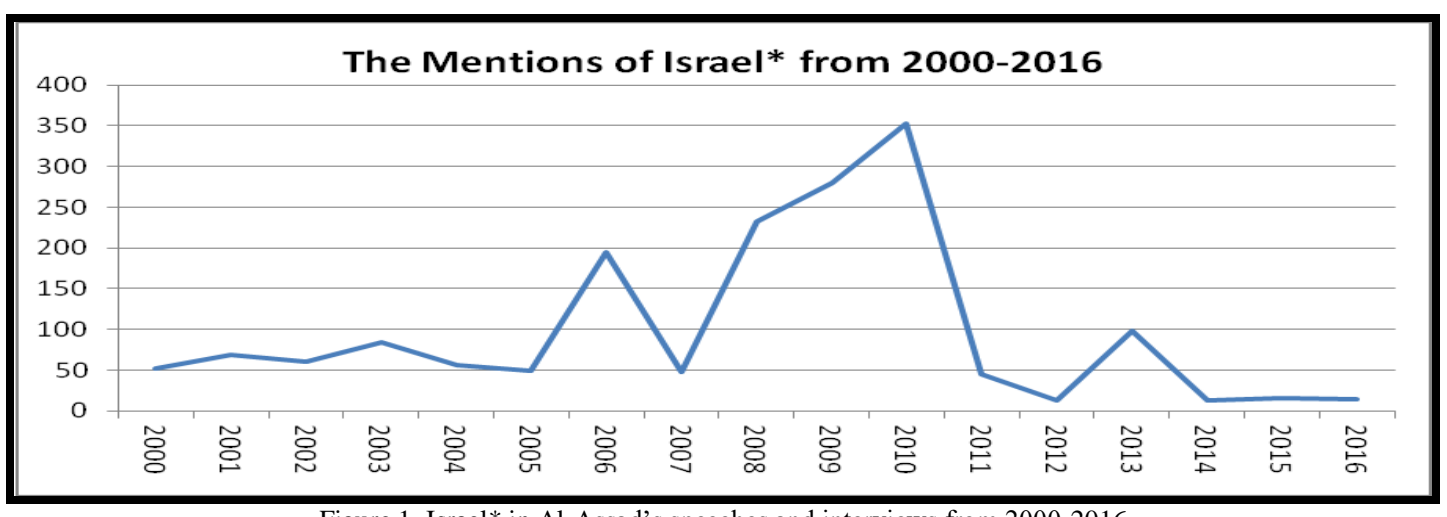

Figure 1. Israel* in Al-Assad's speeches and interviews from 2000-2016

The dispersion analysis of the frequency of Israel shows that Al-Assad refers to Israel more frequently in some years than others. The different peaks in the figure could be due to the varied numbers of speeches and interviews. For example, 33 and 27 speeches were delivered in 2009 (280 mentions of Israel) and 2010 (352 mentions), respectively, while only five speeches and interviews were delivered in 2014 (13 hits of Israel). However, this cannot be applied to other years. For example, Israel was mentioned 195 times in 2006 even though the number of speeches and interviews was only 9. Accordingly, investigating the context to see the different (critical) events between the two investigated countries over the years can better interpret the peaks and troughs in figure 1. It appears that there was a dramatic increase in the use of Israel in four years, namely 2010, 2009, 2008, and 2006. Investigating the context, the researcher found that Israel accused Syria of transferring powerful Scud missiles to Hezbollah in 2010. In 2008/2009, there were peace talks between the two countries, but Syria withdrew after the Israeli war on Gaza. In 2006 Israel-Hezbollah War (Lebanon war) occurred.

Israel before the Uprisings (2000-2010)

The researcher first used the CL technique of collocation to see how Israel is referred to in the pre-uprisings period. Using WS7 and choosing the span of \pm 5 , i.e. five words on either side of the node word, Israel* was identified to collocate significantly with other words based on two collocational statistics: MI and t-scores. Measuring the strength of collocation using these two measures is important. Hunston (2002) proposed that an MI score of 3 or higher can be 
taken as evidence that the two items are collocates. McEnery and Wilson (2001, p. 86) also argue that if the collocating items have "high positive mutual information scores then they are more likely to constitute characteristic collocations than others with much lower mutual information scores." Regarding t-scores, McEnery, Xiao, and Tono (2006, pp. 5657) stated that "t-scores tend to show high-frequency [collocating] pairs' and that '[a] t-score of 2 or higher is normally considered to be statistically significant". Examining the words that collocate with Israel* with the collocation statistics of 3 or more MI scores and two or more t-score intersected, the researcher found that they can be classified into different thematic categories as table 2 shows:

TABLE 2

THEMATIC CATEGORIES OF THE COLLOCATES OF ISRAEL*

\begin{tabular}{|c|c|}
\hline Category & Examples \\
\hline Arab Israeli Conflict & $\begin{array}{c}\text { enemy, military, Hezbollah, Hamas, Arab, occupied, resistance, Golan, Lebanon, } \\
\text { Palestine, Gaza }\end{array}$ \\
\hline Negotiations & peace, negotiations, talks, partner, withdrawal, initiative, ceasefire \\
\hline Israel Internal Affairs & government, Sharon, Rabin, Olmert \\
\hline Criminality/Violence & aggression, killed, massacres, attack, destruction, siege, weapons, war, warplanes, bomb \\
\hline Location & Middle, East, nuclear, region \\
\hline
\end{tabular}

After identifying the most salient related lexical patterns, the researcher carried out a concordance analysis to examine the immediate co-text of these terms. Carrying out concordances is useful in the case of collocations. Although collocation provides the researcher with strong ties or relationships between words, concordance plays an important role in identifying how such types of relation appear in the language.

The Arab-Israeli conflict. The collocates in this category refer to the ongoing Arab-Israeli conflict and portray the Arabs as one unity against Israel, having a shared perspective against its cruel acts, violations, and occupations. On the other hand, Israel is portrayed as the party that creates the problems and makes assaults against the Arabs (concordance $1)$.

\begin{tabular}{|ll|}
\hline $1-$ & release of all Arab detainees imprisoned in Israeli jails and detention camps. \\
$2-$ & forms of cooperation with Israel. The Israeli aggressions against the Arab Nation \\
$3-$ & face the current situation in light of the Israeli assaults in the occupied Arab land. \\
$4-$ & dealing with any aggression staged by Israel against any Arab country as an assault \\
$5-$ & the "land for peace" formula that call upon Israel to withdraw from all Arab territories \\
6- & wants to analyze, it should analyze the Arab-Israeli wars in 1948, 1956, 1967, 1973, 1982 \\
$7-$ & has never worked for peace. The Arab-Israeli conflict is a 60 year old one \\
$8-$ & peace conference, the only forum at which Israel faced all its Arab enemies \\
9- & the Arab People struggle against the Israeli occupation of the Arab Territories \\
\hline
\end{tabular}
Concordance 1. The Arab Israeli conflict in the sub-corpus (2000-2010)

Also, the category comprises words relating to the territories occupied by Israel, including the Syrian Golan Heights, South Lebanon, and Palestine (concordance 2).

1- liberation of most of part of Lebanon from the Israeli occupation, but the situation in Palestine

2- $\quad$ Palestinian refugees' right to return and ending the Israeli occupation of the Syrian Golan

3- leaders only the terrorists!" noting that the Israeli occupation troops are still in Gaza

4- inflicted a humiliating defeat against Israeli occupation troops in South Lebanon.

5- reconciliation protects Palestine from the Israeli aggression, and helps to re-launch peace

6- Lebanon, as we witnessed last year during the Israeli aggression of July against Lebanon

Concordance 2. The Israeli Occupation of Arab territories in the sub-corpus (2000-2010)

Negotiations (Political Aspect). This category includes the collocates related to the peace process with Israel. AlAssad showed his readiness to have peace with Israel on the principle of land for peace formula in addition to demanding Israel to stop its violent and severe acts against Palestinians, especially in the Gaza strip. On the other hand, Al-Assad accused Israel of not having any serious intentions to have such relations since it always puts obstacles on the peace road map. He also emphasized the role that other countries such as Turkey and France play in mediating between the two states (concordance 3). 
peace negotiations between Syria and Israel with the mediation of Turkey.
Time that this is an evidence for us that the Israelis are not serious about peace.
cause of the continued presence of anti-peace Israeli Israeli governments, we could not have
The indirect negotiations have proved that Israel is never willing for peace, nor able
to the line of June 4, 1967. The Israeli non-responding to peace requirements
All those efforts were always blocked by the Israel rejection of peace and met with more wars
confirms Arab readiness for peace...but Israel responded to all this by ignoring peace
and on the principle of land for peace, and Israeli withdrawal from the occupied Golan

Concordance 3. Negotiations between the Arabs and Israelis in the sub-corpus (2000-2010)

Israel Internal Affairs. All words in this category relate to Israeli internal affairs and have the names of former Israeli Prime Ministers. Almost all nouns were represented negatively, showing the Israeli policy's arrogance that only looks for its interest. Regarding the frequency of the Israeli officials, the researcher found that Rabin was mentioned ten times, Sharon 26 times, Barak 9 times, and Olmert 33 times (concordance 4).

\begin{tabular}{|ll|}
\hline $1-$ & the negotiations.. First because this Israeli government expresses an increasing and mounting extremism \\
$2-$ & To see him here in Syria. Betting on Israeli government is a waste of time \\
$3-$ & influenced by the aggressive Israeli policies, and massacres, or whether they were \\
$4-$ & terrorism practised by (Ariel) Sharon (the Israeli Prime Minister) against the civilian Palestinian \\
\hline
\end{tabular}

Concordance 4. Israeli internal affairs in the sub-corpus (2000-2010)

Criminality, Violence, and Siege. This category consists of collocates that describe the harsh acts committed by Israel against the Arabs in general and Palestinians in particular. For example, Al-Assad accused the Israeli government of having a criminal mentality that doesn't distinguish between children or adults. He even said that the Israelis killed Rabin, their former prime minister, because they doubted he would offer a peace process (concordance 5).

\begin{tabular}{|ll|}
\hline $1-$ & Israel can't accuse those innocents ...Israel always kills the innocents, but it couldn't accuse \\
$2-$ & bulldozers that demolished the houses were Israeli bulldozers, but it is true that they had sent \\
$3-$ & against Gaza, which was the result for the Israeli criminal mentality on one side, and the unnatural \\
$4-$ & the Arabs a step-by-step approach. When Israel killed Mohammad Durra in Palestine, there was a \\
$5-$ & ebanese Resistance in less than a year. The Israelis killed Rabin, when they suspected that he would \\
$6-$ & threats have been used as a cover to the Israeli massacres which are perpetrated against
\end{tabular}

Concordance 5. The Israeli violence in the sub-corpus (2000-2010)

Location. All words in this group relate to the location of Israel in a critical area in the Middle East surrounded by Arab countries and being a threat to the whole region (concordance 6).

\section{1- We want a nuclear-free Middle East, Israel included. The Americans are stoking \\ 2- $\quad$ terrorism in the Middle East without Israel being the axis and the essence, is not objetive \\ 3- $\quad$ illusionary enemies in our region to replace Israel as the only enemy is a help for Israel.}

Concordance 6. The location of Israel in the Middle East in the sub-corpus (2000-2010)

\section{After the Uprisings (2011-2016)}

In order to see if Al-Assad's referred to Israel* differently during the era of the Syrian Uprisings (2011-2016) compared with the pre-uprisings era, the researcher carried out a concordance analysis for the node word Israel* and produced 200 lines. The researcher went through these lines manually and found that they can be classified into different categories, as figure 2 shows. 


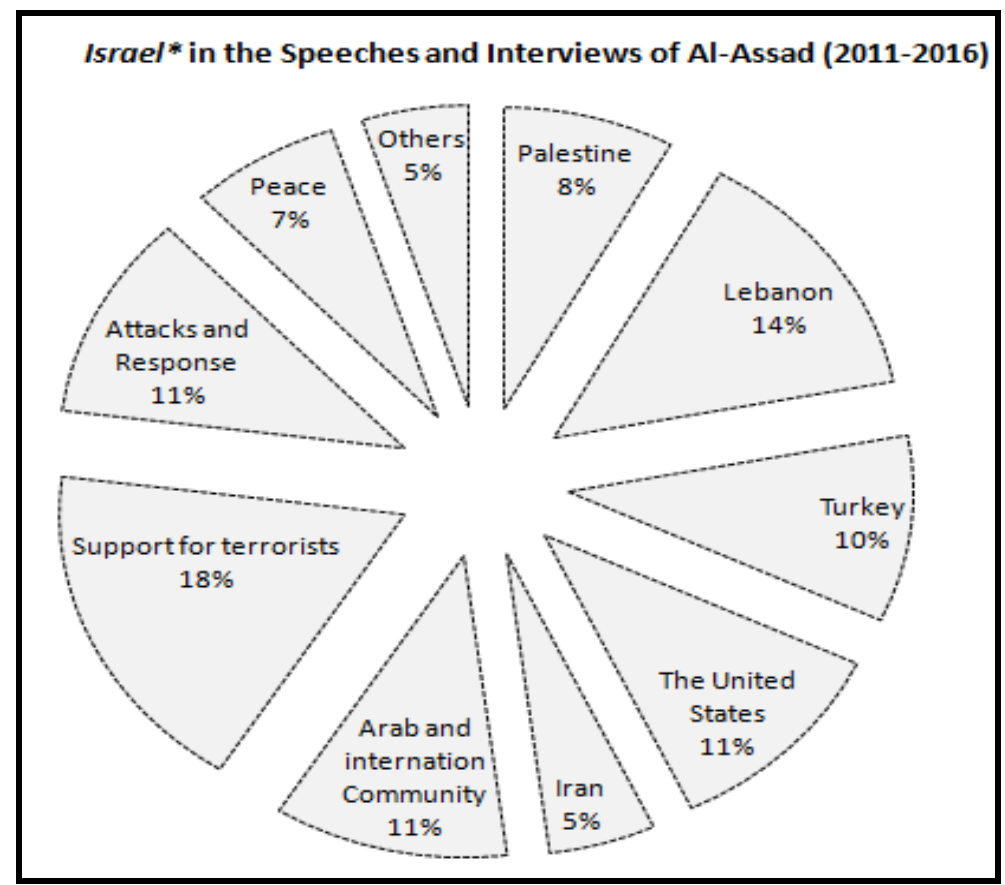

Figure 2. A pie chart of Al-Assad use of Israel* during the uprisings (2011-2016)

Palestine \& Lebanon. Israel* was mentioned in the context of Palestine and Lebanon in about $22 \%$ of the hits as follows:

Palestine. In this period, Al-Assad referred to Palestine differently when compared with the pre-uprising period; he first used it in an analogy to convince the audience (texts' receivers) that what's happening in Syria is not a revolution by any means. Those who think so should accept that the Israeli acts against Palestinians constitute a revolution against Palestinian oppression! He also refers to the Gaza strip in another analogy to deny his country's involvement in any weapons transfer to Lebanon. He states that Gaza is surrounded by both Egypt and Israel (they are both against Hamas) but still has everything available there! He also utilized the Israeli war on Gaza as evidence to show that Erdogan, the Turkish Prime Minister, is a hypocrite as he all the time shows his sympathy and solidarity with the Palestinians, not the Lebanese. However, both were attacked by Israel, and the resistance is strongly present in the two countries. Al-Assad also used Palestine to justify his alliance to Iran, stating that it changed the Israeli Embassy into a Palestinian one and stood with the Palestinians on different occasions. This has not been done even by the Arab States. One last example is related to the use of Palestine to show the negative and passive role that the Arab League plays in some Arab issues, as example 1 below shows:

"It even has not returned one olive tree uprooted by Israel or prevented the demolition of one Palestinian house in occupied Arab Palestine."

Lebanon. Lebanon was used in the context of Israel in Al-Assad's speeches and interviews to show his outrage of the Arab League, claiming that the League has never supported or taken Syria's side in many events, for example, the Israeli aggression against Lebanon. Al-Assad also pointed out that the Arab citizens don't have any confidence in the Arab summits, and they always condemn officials sitting in the halls. He also claimed that there are no Hezbollah fighters inside Syria since they are already deployed towards Israel and cannot leave southern Lebanon; however, he mentioned that they aided the Syrian Army in cleaning the Lebanese borders from terrorists! In answering a question regarding Al-Qusair, a border city with Lebanon, Al-Assad justified Hezbollah's presence and claimed that their battle there is against Israel and its agents, referring to the rebels and defectors from the Syrian Army in Al-Qusair. Al-Assad also referred to the Israeli War on Lebanon in 2006 to show that the Israeli super-power in the Middle East could not defeat a small faction.

Turkey. Turkey was also present in the context of Israel* in Al-Assad's speeches after the uprisings. He tended to refer to the policies of Erdogan, the Turkish Prime Minister at that time, rather than Turkey as a state to highlight the idea that both Israel and Turkey are taking benefit of what's happening in Syria. They are even working hard to aggravate the situation there since they have some interests in it, claiming that they turned out to be strong allies walking shoulder to shoulder in order to damage Syria. Al-Assad also criticized Turkey for deploying missiles shields on its borders to protect Israel. He also referred to Turkey's role as an arbiter between his country and Israel in the past.

The United States. Al-Assad criticized the biased and double-standard foreign policy of the United States towards Israel and against the rights of the Arab People. He claims that the Israeli aggression against Syria is in defense of the US interests in the region, accusing America of allowing Israel to have a weapon of mass destructions (WMDs) in the Middle East while standing firm against any other countries who might have intentions to do so (like Iran), in addition to supporting the crimes committed by the Israelis. Al-Assad also tended to refer to Israel and America as one unity 
having special relations, highlighting that this is logical as both countries committed massacres in Palestine, Afghanistan, and Iraq.

Iran. Syria represents Iran's closest ally in the Arab world; such relation has always been criticized by many Arab political analysts since the ruling party in Syria, represented by Al-Baath party, follows, to some extent, secular standards. In contrast, Iran apparently follows pan- Islamist strategies. In common, Iran and Syria have similar reactions toward some countries, such as America and Israel on the one hand and Russia and China on the other hand. Some studies (see Khalaji, 2013) describe the relationship between these two countries as religious since the Syrian leadership belongs to the Alawite branch of Shi'a Islam. Although all of these common aspects, Al-Assad tended to talk about Syria's relations with Iran objectively in most cases. In a question about Hezbollah, Al-Assad declared that the group is supported by many countries publicly and secretly, and the whole issue doesn't relate to Iran. In a question regarding the role of Iran in the American-Syrian relations, Al-Assad replied (example 2):

"What does Iran mean? Is it bad? Okay. Israel is bad, so how are you going to make peace with Israel...... So, if they do not like Iran, this does not mean that you do not have to deal with it."

Al-Assad also avoided answering some questions related to the Iranian nuclear weapon file, stating that he is not a part of it and it is their own file based on their national interest. He also claimed that Syria doesn't have a special file called Iran since all the Syrian government cares about is the peace file. Al-Assad also emphasized that Iran supports but does not control Syria (concordance 7).

\begin{abstract}
Question: Some critics say that you have sold your country to Iran, and that you would not survive without the help of Iran and Hezbollah. Is it true?

President Assad: If I wanted to adopt this principle, to be ready to sell my country, I would have sold it to the United States, maybe to Israel, maybe to Saudi Arabia, because many countries since the independence of Syria wanted to control Syria for geopolitical reasons. So, if I wanted to sell, I would sell it to the United States first. So, as long as I don't sell it to anyone, I wouldn't sell it to Iran. This is first. Second, Iran never tried to control my country. Never. And the Syrian people, by nature, they won't accept anyone to control their country. So, when Iran supports Syria, that doesn't mean it controls, doesn't mean it tries to impose what it wants on the Syrian government. What you say, we couldn't survive without Iran and Hezbollah, this is a hypothetical question for one reason: sometimes small support in a big war will lead you to bigger results, in any war or any conflict, will give big results. So, whether this support is small or big, it has given a result, we cannot deny this, and their position, supporting Syria, was vital for us. But how was it without their support is difficult to tell. It must have been more difficult, but that doesn't mean that we couldn't survive.
\end{abstract}

Concordance 7. Iran in the context of Israel* in the sub-corpus (2011-2016)

Arabic and International Communities. Al-Assad accused the Arab countries of having bad intentions and vile objectives, especially after activating a boycott against his country, stressing that he did his best in order to activate the Israel-boycott office, but always received excuses from some Arab countries. He also claims that the Arab countries have forgotten that their real enemy is Israel (line 1, concordance 8). Al-Assad also criticized the international community's attempts to prevent arming Syria, pointing out that they are not occupying anybody's land like Israel that has always been supported to have all kinds of weapons, including the nuclear ones (line 2).

1- $\quad$ Saudi Arabia was ready to offer anything to Israel for nothing in return. It was worried
about the US reaction following the $9 / 11$ attacks and the involvement of Saudis in these attacks
$2-\quad$ We should know that what is happening today in Gaza, ladies and gentlemen, is not a separate
or passing event. It is an integrated chain of events: from the occupation of Palestine, to the
invasion of Iraq and trying to divide it now and the division of the Sudan all planned by Israel and
the West and always executed by the states of tyranny and backwardness in our Arab world

Concordance 8. Arab and international community in the context of Israel* (2011-2016)

Peace. Al-Assad wanted to prove to the whole world that he is the man of peace and does his best to achieve it in the region, but he usually faces negative responses and deeds from other parties (Israel). Therefore, he also emphasized the necessity of peace and stability in such a hot area of the world, highlighting that Israel should show a strong commitment to it by withdrawing from the Arab's occupied lands.

Syrian Uprisings. Israel and its involvement in what's happening in the Syrian Arena constitute 29\% in figure 2 . The researcher divided the concordance lines regarding this topic into two categories:

Attacks and Response. During the latest events in Syria, Israel carried out airstrikes against Damascus, claiming that it attacked a nuclear site under construction. Al-Assad stated that Israel intends to stifle the resistance and strike the Syrian air defense system. In response to a question regarding Syria's muted response to this attack, Al-Assad replied that Syria would respond the next time (line 1, concordance 9). In the co-text of Israel, Al-Assad justified the arming contracts with Russia, especially the S300 air defense system, by saying that it is a way to strengthen their traditional arsenal and enhance their power against any expected enemies (line 2). Al-Assad also stated that Syria's retaliation to 
any Israeli attack will be through a strategic response, citing the popular Syrian pressure to open the Golan front to resistance. Al-Assad also highlighted the Syrian feelings to assist their Army in fighting the Israeli aggression.

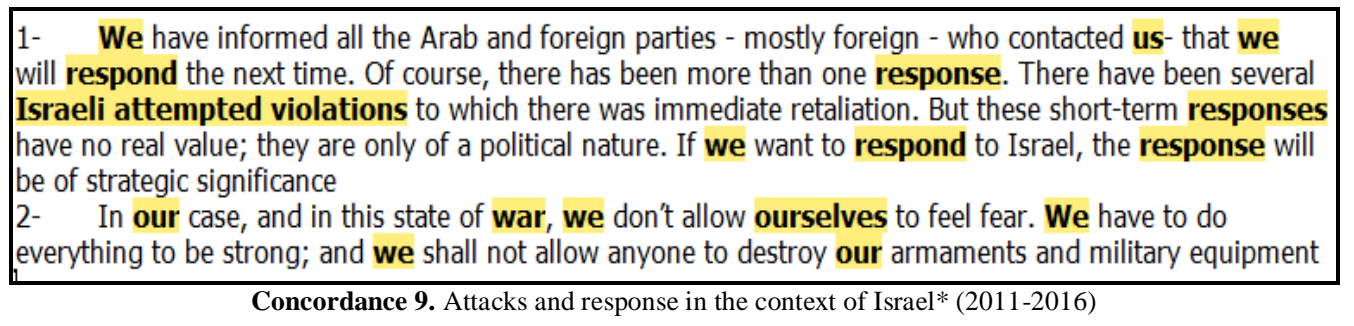

Support for terrorists. What draws my attention in the use of Israel in Al-Assad's speeches and interviews (20112016) can be summarized in this category. He first accused and blamed the Arab community, and then moved to blame the international community and the United States, before moving to accuse Israel of helping terrorists and providing them with weapons, food, and medical treatment to destroy Syria and stifle the resistance (lines 1/2/3, concordance 10). Al-Assad also rejected conducting any dialogue with the opposition, claiming direct relations with Israel (line 4). However, Al-Assad sometimes reduced the tone of accusation of Israel. For example, in response to a question regarding the source of weapons and ammunition, mainly Israeli explosives, Al-Assad said that other countries might also be involved in this (line 5).

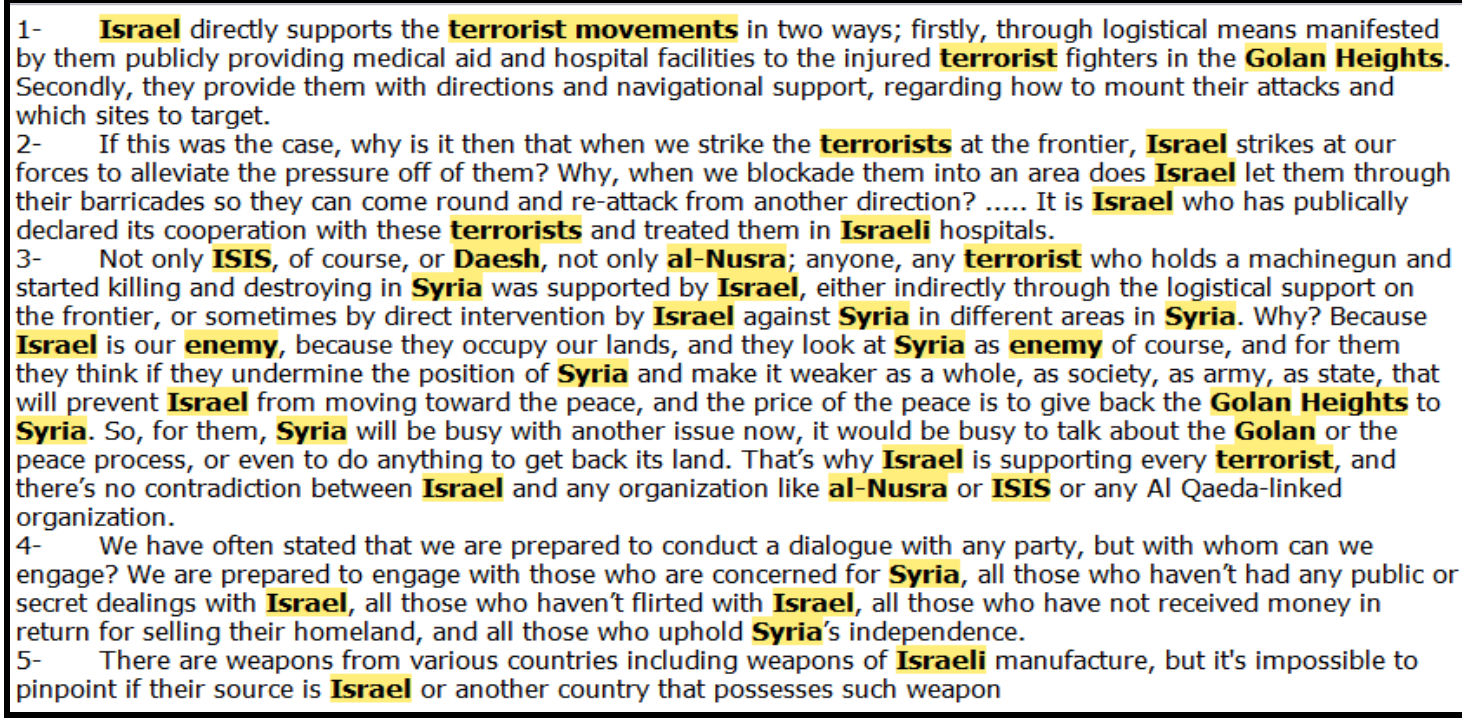

Concordance 10. Terrorism in the context of Israel* (2011-2016)

\section{CDA Notions of MANipUlation/ POlARisation/ IDEOLOGY AND THE CURRENT STUDY}

Manipulation is one of the crucial notions in CDA since it represents a form of power and abuse of power (domination). This significant notion usually occurs in texts and talks. In the current study, Bashar Al-Assad controlled some of the texts' receivers and manipulated them. Van Dijk (2006) points out that manipulation can mentally manipulate the receivers' mind and is usually portrayed as a negative concept that tends, in most cases, to violate social form. It may be argued that this is not the case in the investigated corpus since most people in the Arab world have already had hostility towards Israel. This is true for many reasons, such as wars, occupation, etc., and the researcher thinks that Al-Assad doesn't need to manipulate them regarding this matter since Arabs' hatred towards Israel is already there. However, what the researcher meant by manipulation here has nothing to do with violating the Arab social norms represented by their animosity to Israel but reinforcing it. Why? Al-Assad wants to build a kind of intimacy with his own people, in particular, and those who hate Israel, in general, and whiten his own image by portraying himself as the one who represents people's feelings and points of view in confronting any aggression that does not only target Syria but any other Arab countries.

Let's be more positive and consider manipulation here as a form of persuasion (O'keefe, 2002), i.e. leaving the participants free to act the way they want based on whether they believed and trusted the text's producer or not. However, this cannot be applied here since negativity is apparent in Al-Assad's speeches and interviews. Many people were victims of his manipulation; i.e., they were unable to understand his intention or recognize the consequences of his opinions and policies. Accordingly, drawing a boundary between persuasion and manipulation is not easy. However, it 
is a battle between what is legitimate and illegitimate. The whole issue is intricate since it depends on many factors, such as the involved people, circumstances, and others.

To have a better understanding of this, the researcher used Van Dijk's triangular approach (2009) that includes social aspects (interaction of social actors overpower), cognitive aspects (occurring in the participants' mind), and discursive aspects (speeches and interviews). To begin with the macro level, Al-Assad has most of the social conditions of manipulative control; he is the president, the most powerful person in the group, represents power and authority, and has complete access and control over resources and materials including mass media and public discourse. Having all of these factors, he can gear lots of people towards reproducing his discourse, sometimes legitimately through persuasion. The second factor in van Dijk's approach is related to cognition, where Al-Assad manipulated some of his people's minds, i.e. their beliefs (knowledge and opinions), and ideologies that control their actions and shape their behaviors. He frequently emphasizes the points consistent with his interests, i.e. his good attributes and deeds, and de-emphasizes the points inconsistent with his interests, i.e. his bad deeds. He also tends to blame the other side by hampering his good intention for peace. By repeating these aspects of polarisation (We vs. They) or Us (good, innocent), and Them ( evil, guilty), the model formation will be automatized in the recipient short term memory (STM), bearing in mind that most Arab people have a special place in their episodic memory (LTM) that is full of hostility towards Israel, so what AlAssad is simply doing is recalling these abstract mental attitudes and ideologies since he has already had the privilege of stable, permanent, and socially shared beliefs and attitudes for almost the whole group. Once people's attitudes are influenced, for instance, on the necessity of getting rid of Israel from the region, little or no further manipulation attempts may be necessary for the people to act according to these attitudes, for instance, to vote in favor of Al-Assad regime which represents the anti-Israeli policies (Chomsky, 2003). Al-Assad was successful, to some extent, since he uses some cognitive mechanisms of manipulation (Van Dijk, 2006), such as referring to the Israeli's cruel acts and massacres against Arabs, which have a very strong impact on people's minds, influencing them to have the desired mental model. Another mechanism is achieved by repeating messages and grouping related events going back sometimes to some events that happened 70 years ago to justify his point of view regarding some issues in the regions. He did his best to convince his people that he was doing so for the sake of the nation (Us) and to protect the country from others' aggregation (Them). The third aspect in van Dijk's socio-cognitive approach is related to discourse; AlAssad uses different strategies to highlight the idea of the ideological square of discursive group polarisation (Van Dijk, 2003), as table 3 shows.

TABLE 3

VAN DIJK'S IDEOLOGICAL SQUARE

\begin{tabular}{|c|c|}
\hline WE/Us ( in-group Members) & They/ Them (out-group Members) \\
\hline emphasize good things (deeds) & emphasize bad things (deeds) \\
\hline de-emphasize bad things (deeds) & de-emphasize good things (deeds) \\
\hline
\end{tabular}

Al-Assad tends to use positive self-presentation and negative others' presentation in favor of his own interests. What is interesting here is that the "others," according to Al-Assad, are represented by the U.S, Israel, and some international countries (before the uprisings) in addition to most of the Arab countries, terrorists, and oppositions (during the uprisings). To put it briefly, almost all countries except Iran, Russia, China, and Hezbollah are Al-Assad's enemies!

The ideological strategies used in the speeches and interviews of Al-Assad includes the use of rhetorical figures such as metaphors (lines 1 and 2 in concordance 11); macro speech act implying Our 'good' acts and Their 'bad' acts, e.g. accusation, defense (lines 3 and 4); semantic macrostructures: topic selection: (De-) emphasize negative/ positive topics about Us/Them (lines 5 and 6); lexicon: select positive words for Us, negative words for Them (lines 7 and 8); and emotionalizing the argument (lines 9 and 10).

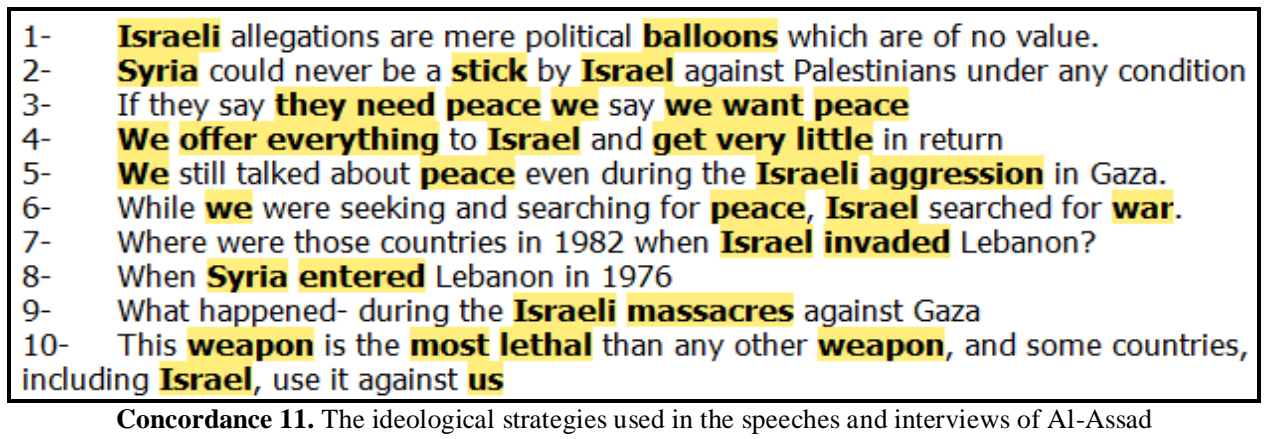

Since manipulation in the speeches and interviews of Al-Assad involves power abuse, as discussed before, it also has some ideological aspects. For example, Bashar Al-Assad frequently refers to Lebanon, Iraq, and Palestine to promote Pan-Arabism, nationalism, and anti-capitalism ideologies. However, Al-Assad also keeps referring to the Israeli cruel and violent acts against Arabs, perhaps because Syria is not involved in the peace treaties with Israel, but would it be the case if Al-Assad himself signed a peace agreement with Israel? Accordingly, it seems that Al-Assad wants to 
increase his popularity and supporters by adopting such hostility against Israel, although it could not be the reality. It is worth noting here that it is unnecessary for all texts' receivers to be manipulated as only having a large group of people manipulated is more than sufficient for the speaker to achieve his goals. What helped Al-Assad to manipulate others lies in their lack of enough counter-information and arguments to resist his manipulative discourse; however, after the outbreak of the Syrian uprisings, Al-Assad got the opportunity to react to the Israeli airstrikes but has not done anything so far being a great talker and a little doer.

\section{CONCLUSION, RECOMMENDATIONS AND IMPLICATIONS}

The relations between Syria and Israel are complicated to be judged, and people wonder whether it is real or a part of the dirty political game. However, the analysis here may contribute to understanding the nature of Syria-Israel relations. Syria, according to Al-Assad, has always been trying to open the channels of conversation and conduct dialogues with Israel which has always been hindering the whole process. It also seems that Al-Assad did his best in order to whiten his page in front of his people and show a kind of intimacy with them by showing hatred to Israel, which represents their first enemy. Unlike many other CDA-based approaches, the corpus analysis used in this study directed me towards salient or frequent linguistic patterns. Combining both the quantitative and qualitative approaches offered me two things as described by McEnery and Wilson (2001, p. 77), and these include having a "greater precision and richness" of qualitative analysis as well as having statistically "reliable and generalizable results" of quantitative studies. In conclusion, this study recommends CDA researchers to carry out their studies with the aid of CL techniques since it allows them to change the traditional way of doing discourse analysis and gives them a sense of generalization.

\section{ACKNOWLEDGMENTS}

The author is grateful to the Middle East University, Amman, Jordan for the financial support granted to cover the publication fee of this research article.

\section{REFERENCES}

[1] Al-Abbas, L. S., \& Haider, A. S. (2020). The representation of homosexuals in Arabic-language news outlets. Equality, Diversity Inclusion: An International Journal. doi:https://doi.org/10.1108/edi-05-2020-0130

[2] Baker, P. (2006). Using corpora in discourse analysis: A\&C Black.

[3] Baker, P. (2010). Sociolinguistics and corpus linguistics. Edinburgh: Edinburgh University Press.

[4] Baker, P., Gabrielatos, C., Khosravinik, M., KrzyŻAnowski, M., McEnery, T., \& Wodak, R. (2008). A useful methodological synergy? Combining critical discourse analysis and corpus linguistics to examine discourses of refugees and asylum seekers in the UK press. DISCOURSE \& SOCIETY, 19(3), 273-306. doi:10.1177/0957926508088962

[5] Bartsch, S. (2004). Structural and functional properties of collocations in English: A corpus study of lexical and pragmatic constraints on lexical co-occurrence. Tübingen: Gunter Narr Verlag.

[6] Chomsky, N. (2003). Hegemony or Survival: America's Quest for Global Dominance. New York: Henry Holt.

[7] Fairclough, N. (2009). A dialectical-relational approach to critical discourse analysis in social research. In R. a. M. Wodak, M. (Ed.), Methods of critical discourse analysis (Vol. 2, pp. 162-187). London: Sage.

[8] Fairclough, N., \& Wodak, R. (1997). Critical Discourse Analysis. In T. A. van Dijk (Ed.), Introduction to Discourse Analysis. (pp. 258-284.). London: Sage.

[9] Gabrielatos, C., \& Baker, P. (2008). Fleeing, Sneaking, Flooding: A Corpus Analysis of Discursive Constructions of Refugees and Asylum Seekers in the UK Press, 1996-2005. Journal of English Linguistics, 36(1), 5-38. doi:10.1177/0075424207311247

[10] Haider, A. S. (2016). A corpus-assisted critical discourse analysis of the Arab uprisings : evidence from the Libyan case. (PhD), University of Canterbury, New Zealand.

[11] Haider, A. S. (2019a). Syrian-Lebanese Relations: A Corpus-based Critical Discourse Analysis of Bashar Al-Assad's Speeches and Interviews. Dirasat, Human Social Sciences, 46(4), 551-570.

[12] Haider, A. S. (2019b). Using corpus linguistic techniques in (critical) discourse studies reduces but does not remove bias: Evidence from an Arabic corpus about refugees. Poznan Studies in Contemporary Linguistics, 55(1), 89-133. doi: https://doi.org/10.1515/psicl-2019-0004

[13] Haider, A. S. (2019c). The Representation of Al-Megrahi's Release in Arabic and English Newspapers in 2009 and 2010: A Corpus-assisted Discourse Study. Dirasat, Human Social Sciences, 46(1 Supplement 2), 297-317.

[14] Haider, A. S., Al-Salman, S., \& Al-Abbas, L. S. (2021). Courtroom Strong Remarks: A Case Study of the Impact Statements from Survivors and Victims' Families of the Christchurch Mosque Attacks. International Journal for the Semiotics of LawRevue internationale de Sémiotique juridique, 1-18. doi: https://doi.org/10.1007/s11196-021-09872-4

[15] Haider, A. S., \& Hussein, R. F. (2019). Analysing headlines as a way of downsizing news corpora: Evidence from an ArabicEnglish comparable corpus of newspaper articles. Digital Scholarship in the Humanities, 35 (4), 826-844. doi: https://doi.org/10.1093/llc/fqz074

[16] Haider, A. S., \& Olimy, S. (2019). The Representation of Laji'een (Refugees) and Muhajireen (Migrants) in the Headlines of Jordan News Agency (PETRA). International Journal for the Semiotics of Law-Revue internationale de Sémiotique juridique, 32, 155-186. doi:10.1007/s11196-018-9550-4

[17] Hardt-Mautner, G. (1995). Only Connect.' Critical discourse analysis and corpus linguistics'. . UCREL (University Centre for Computer Corpus Research on Language). Technical Papers 6: Lancaster University. Retrieved May 26, 2021,from http://ucrel.lancs.ac.uk/papers/techpaper/vol6.pdf.

[18] Hunston, S. (2002). Corpora in Applied Linguistics. Cambridge: Cambridge University Press. 
[19] Khalaji, M. (2013). Iran-Syria Religious Ties. Retrieved June 15, 2021, from https://iranprimer.usip.org/blog/2013/jun/03/parti-iran-syria-religious-ties

[20] Küçükkeleş, M. (2012). Arab League’s Syrian Policy. SETA. Retrieved June 20, 2021 from http://setadc.org/pdfs/SETA_Policy_Brief_No_56_Arab_Leagues_Syrian_Policy.pdf.

[21] McEnery, T., \& Wilson, A. (2001). Corpus linguistics. Edinburgh: Edinburgh University Press.

[22] McEnery, T., Xiao, R., \& Tono, Y. (2006). Corpus-based language studies: An advanced resource book: Taylor \& Francis.

[23] O'Halloran, K. (2000). Mystifying discourse: a critique of current assumptions and an alternative framework for analysis. $(\mathrm{PhD})$, Murdoch University, Australia.

[24] O'keefe, D. J. (2002). Persuasion: Theory and research. Thousand Oaks, CA: Sage.

[25] Schegloff, E. A. (1997). Whose text? Whose context? DISCOURSE \& SOCIETY, 8(2), 165-187. doi:10.1177/0957926597008002002

[26] Scott, M. (2016). WordSmith tools version 7. Stroud: Lexical Analysis Software.

[27] Sharrock, W. W., \& Anderson, D. C. (1981). Language, Thought and Reality, Again. Sociology, 15(2), 287-293.

[28] Stubbs, M. (1997). Whorf's children: Critical comments on critical discourse analysis (CDA). In R. A. \& W. A. (Eds.), Evolving Models of Language: British Studies in Applied Linguistics (Vol. 12, pp. 100-116). Clevedon: Multilingual Matters.

[29] Stubbs, M. (2001). Words and phrases: corpus studies of lexical semantics. Malden, MA; Oxford: Blackwell Publishers.

[30] Van Dijk, T. A. (1995). Discourse analysis as ideology analysis. In C. S. a. A. L. Wenden (Ed.), Language and peace (pp. $17-$ 33). Dartmouth: Aldershot.

[31] Van Dijk, T. A. (2003). Critical discourse analysis. In D. Schiffrin, Tannen, D.,Hamilton, H.E. (Ed.), The handbook of discourse analysis. (pp. 352-371). Oxford: Blackwell.

[32] Van Dijk, T. A. (2004). From Text Grammar to Critical Discourse Analysis. A brief academic autobiography. Retrieved April 19, 2021 from http://www.discourses.org/From\%20text\%20grammar\%20to\%20critical\%20discourse\%20analysis.html

[33] Van Dijk, T. A. (2006). Discourse and manipulation. DISCOURSE \& SOCIETY, 17(3), 359-383.

[34] Van Dijk, T. A. (2009). Critical discourse studies: A sociocognitive approach. Methods of critical discourse analysis, 2(1), 6286.

[35] Van Leeuwen, T. (2006). Critical Discourse Analysis. In K. Brown (Ed.), Encyclopedia of language and linguistics (Vol. Vol. 3, pp. 290-294.). Oxford: Elsevier.

[36] Wodak, R. (2009). What CDA is about - a summary of its history, important concepts and its developments. In R. M. Wodak, M (Ed.), Methods of critical discourse analysis. London: Sage Publications.

Linda S. Al-Abbas is an Assistant Professor at the Department of English Language and Literature, Middle East University/ Jordan. Dr. Al-Abbas received her PhD in Linguistics from the University of Jordan/ Jordan. Her main areas of interest include gender studies, discourse analysis, semantics and translation. 